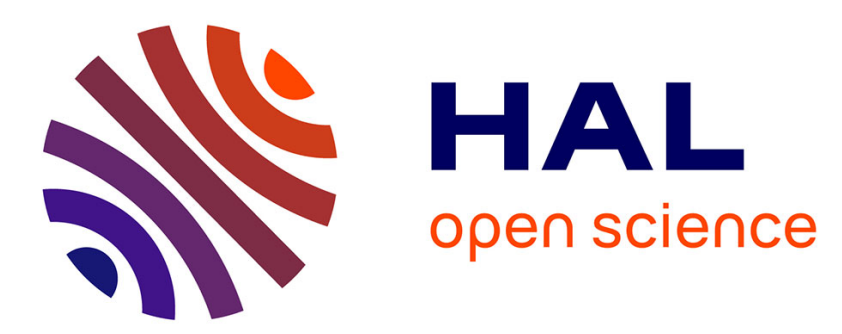

\title{
Mechanically Q-switched co-doped Er-Yb glass laser under Ti:Sapphire and laser diode pumping
}

\author{
Eric Tanguy, Jean-Paul Pocholle, Gilles Feugnet, Christian Larat, M.
}

Schwartz, Alain Brun, Patrick Georges

\section{- To cite this version:}

Eric Tanguy, Jean-Paul Pocholle, Gilles Feugnet, Christian Larat, M. Schwartz, et al.. Mechanically Qswitched co-doped Er-Yb glass laser under Ti:Sapphire and laser diode pumping. Electronics Letters, 1995, 31 (6), pp.458. hal-00762049

HAL Id: hal-00762049

https://hal-iogs.archives-ouvertes.fr/hal-00762049

Submitted on 4 Feb 2014

HAL is a multi-disciplinary open access archive for the deposit and dissemination of scientific research documents, whether they are published or not. The documents may come from teaching and research institutions in France or abroad, or from public or private research centers.
L'archive ouverte pluridisciplinaire HAL, est destinée au dépôt et à la diffusion de documents scientifiques de niveau recherche, publiés ou non, émanant des établissements d'enseignement et de recherche français ou étrangers, des laboratoires publics ou privés. 
Mechanically Q-switched codoped Er-Yb glass laser under Ti:sapphire and laser diode pumping

E. Tanguy, J.P. Pocholle, G. Feugnet, C. Larat, M. Schwarz, A. Brun and P. Georges

Indexing terms. Optical pumping, Q-swutching. Solid lesers

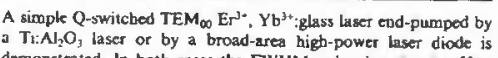
and the pat. In both cases the FHM pulse duration is a soms

A compact laser emitling in the 1.5 um eye-sufe wavelength range finds very interesting applications in the felds of telemetry or optcal communications [1]. Codoped $\mathrm{Er}^{3+}$. $\mathrm{Yb}^{3 *}$ phosphate glass [2] and a purnped laser diode lead to a low-cost, compact microlaser emitting at this wavelength [3].

In this letter an $\mathrm{Er}^{3 *}: \mathrm{Yb}^{3}$ microlaser pumped by a $\mathrm{Ti}: \mathrm{Al}_{2} \mathrm{O}$ laser and a broad-area laser diode are presented. Contipuous and Q-switched operations were performed. "The laser cavity shown in

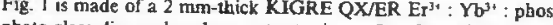
phate glass disc and a plane output mirror. One face of the disc is high-reflectivity-coated at $1540 \mathrm{am}(R>99.9 \%)$ and the transmis sion at $980 \mathrm{~nm}$ is abour $95 \%$. The other disc face is antireflection. coated at $1540 \mathrm{~nm}(R<0,03 \%)$. The output mirror reflection is estimated to be $-99 \%$ at $1535 \mathrm{~nm}$. The overall cavity length is 2.5

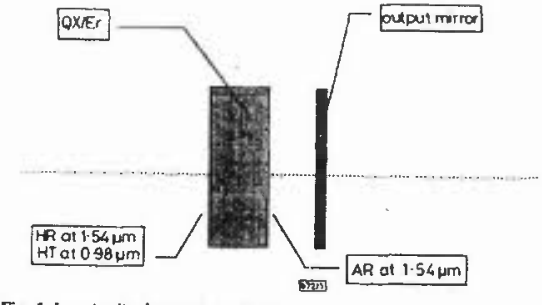

Fig. 1 Longitudinal pumping schem

A $200 \mathrm{~mm}$ lens focuses the $\mathrm{Ti}_{\mathrm{i}} \mathrm{Al}_{2} \mathrm{O}$, laser operating at $\lambda=$ $980 \mathrm{~nm}$ leading to a measured spot radius within the disc of
$-100 \mu \mathrm{m}$. The Rayleigh range of the pump beam is about $2 \mathrm{~cm}$. Thus the spot size can be considered constant into the active mato rial. The output power from the $\mathrm{E}^{\mathrm{s}^{3}+}, \mathrm{Y}^{3}{ }^{3+}$. glass loser is shown in Fig. 2 as a function of the pump power.

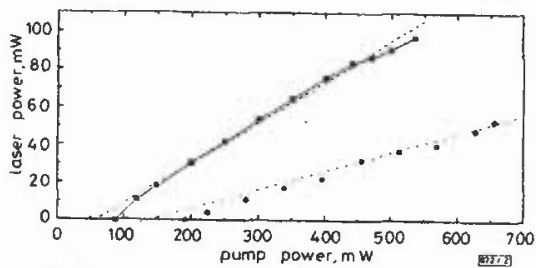

Ftg. 2 Oulput power againss pump power

Titanium-sapphire pumped Er:Glass laser:

- measured daca

analysis cakculated dat

. measured data

ratc equation analysis calculated data

The power was measured by a thermopile power meter. A semiconductor filter rejects the unabsorbed pump power. The maximum output power obtained is $100 \mathrm{~mW}$ at a $540 \mathrm{~mW}$ pump power level. The optical-optical efficiency is $18.5 \%$, the laser threshold is $90 \mathrm{~mW}$ and the slope efficiency is $22 \%$. The measured outpul beam was almost diffraction-limited $(A R=1.3)$ with a $7 \mathrm{mrad}$ angular divergence leading to an intracavity beam radius of $290 \mu \mathrm{m}$. As expected in a plano-plano cavity, the intracavity and the pump beam have almosi the same dimension.

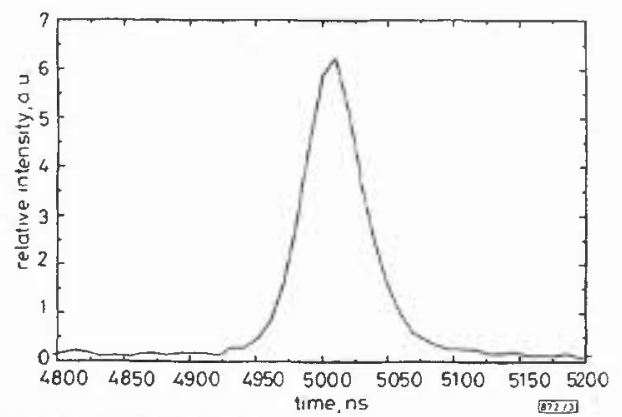

Fig. 3 Tomporal pulse shape

$\mathrm{FWHM}=48 \mathrm{~ns}$, energy $=9 \mu \mathrm{J}$, peak power $=180 \mathrm{~W}$

A one-slit ( $1 \mathrm{~mm}$-width) mechanical chopper is inserted into the cavity between the active material and the output mirror (cayity length $=8 \mathrm{~mm}$ ). With this cavity length the laser is less efftcient. The CW output power is about $30 \mathrm{~mW}$ for a $360 \mathrm{~mW}$ pump level used. Q-swilch operation was observed at $140 \mathrm{~Hz}$ repetition rate. The FWHM pulse duration is $48 \mathrm{~ns}$ as shown in Fig. 3 and the pulse energy is $8.6 \mu \mathrm{J}$ (measured with a pyroelectric joulemeter). Thus the peak power was estimated to be $180 \mathrm{~W}$. The Q switch mode average power is $1.2 \mathrm{~mW}$. The average power should be the same order of magnitude as that in $\mathrm{CW}$-mode operation. $\mathrm{A}$ possible explanation is that the Q-switch rise time is not fas enough $(\sim 5 \mu s)$ to release the stored energy completely.

The same cavity laser configuration was pumped by a broad. area high-power fibre pigtailed laser diode emitting at $-980 \mathrm{~nm}(\Phi$ $=200 \mu \mathrm{m}$ ). The pump bearn angular divergence at the output of the fibre FWHM is $15^{\circ}$. The optical fibre was in contact with the active material. An optical-optical efficiency of $8 \%$ is obtained (see Fig. 2). The laser threshold is $190 \mathrm{~mW}$ and the slope efficiency is $11 \%$. The beam profiles are almost Gaussian but an $M^{2}$ measure ment was not performed.

In the laser-diode-pumped configuration, the thrcshold power is iwice as high and the slope efficiency is twice as small as in the titanium-sapphire pumped conliguration. A possible explanation is that the laser-diode beam is divergent whereas the titanium-sapphirc beam is almost collimated in the active material.

In the Q-switched regime, 52 ns FWHM pulses are obtained. In that case. the chopper disc presents three $0.5 \mathrm{~mm}$-width slits. The measured energy per pulse is $6.2 \mu \mathrm{J}$. Thus the peak power is $120 \mathrm{~W}$ for a $650 \mathrm{~mW}$ pump power level.

As shown in Fig. 2, the experimental data are well fitted in both cases by a rate equation analysis. This one differs from the model published by Laporta $e t$ al. [4] because it takes into account the nonconstant energy transfer between $\mathrm{Er}^{3+}$ and $\mathrm{Yb}^{3+}$. As no shortering of the erbium ${ }^{4} I_{1, Y Z}$ level lifetime was observed, the 'up-conversion' phenomenon is not considered in this model.

The thresholds are high because of the large intracavity spot size. The plano-plano cavity is only stabilised by the gain-guiding and/or the thermal lens. A planoconcave cavity with an appropriate radius of curvature might have a smaller spot size and lead to a smalter threshold [5]. However, this cavity configuration was not studied because a goal of this work is to make a microchip, and i is more difficult to make it with a planoconcave cavity configuration.

In conclusion, we have demonstrated a simple, efficient and compact Q-switched $T E M_{00} \mathrm{Er}^{3 *}: \mathrm{Yb}^{3+}$ lascr end pumped by a $\mathrm{Ti}: \mathrm{Al}_{2} \mathrm{O}_{3}$ laser and by a broad-area high-power taser diode. In both cases, the FWHM pulse duration is $-50 \mathrm{~ns}$ and the peak power is $>100 \mathrm{~W}$.

E. Tanguy, J.P. Pocholle, G. Feugnet, C. Larat, M. Schwarz, A. Brun and $\mathrm{P}$. Georges (Laboratoire Ceniral de Recherches, Thomson-CSF,

Referemces

1 GAPONTSEV, V.P. MATITSIN, SM, ISINEER, A A, and KRAVCHENKO, VB: 'Erbium glass and their applications'. Opt. stion jang a

SHIBIN MANG et al.: Laser and thermal performance of a new erbium doped phosphate laser glass'. KIRGE Inc. lochnical paper LAPORTA, P., TACCHEO.S, LONGHI.S, and SVELTO. O.: 'Diodepumped microchip Er-Yb:glass laser', Opt. Leth. 1993, 18, pp.

4 JAPORTA, P, IONGHI.S, TACCHEO.S. and SVELTO. O: 'Analysis and modeling of the erbium-ytterbium laser", Opt. Commun., 1993, 100, pp. $311-321$

5 LAPORTA, P, TACCHEO. S., and SVELTO, 0 .: 'High power and high efficiency diode-pumped Er:Yb:glass laser', Electron. Len.. 1992, 28, pp. 490-492 